\title{
Variation in Dual Citizenship Policies in the Countries of the $E U$
}

\author{
Marc Morjé Howard \\ Georgetown University
}

\begin{abstract}
While the concept of citizenship has received considerable scholarly attention in recent years, few studies focus on the increasingly prevalent reality of dual citizenship, or full membership - with its respective rights, privileges, and obligations - in two different countries. The main objective of this article is to conceptualize, measure, and classify variation in dual citizenship in the countries of the European Union. I start by recounting the historical opposition to dual citizenship and by describing its emergence in recent decades. I then develop a "Citizenship Policy Index" that accounts for some of the intricacies associated with citizenship policies in general and dual citizenship policies in particular. I go on to apply these measures to the fifteen "older" EU countries in both the 1980s and the contemporary period - thus allowing for an analysis of the changes that have taken place over the past two decades - while also briefly examining the current policies of the ten new EU members. Overall, the findings point to surprisingly resilient national differences that stand out in contrast to the EU's institutional "harmonization" in so many other areas.
\end{abstract}

Despite the recent renewal in the scholarly attention to comparative citizenship, one element within this burgeoning literature that has remained relatively unexplored is the increasingly prevalent reality of dual citizenship, or full membership - with its respective rights, privileges, and obligations - in two different countries. ${ }^{1}$ In today's mobile, interconnected, and international world, many children are being born either to parents from two different countries or on the soil of the increasing number of countries that allow for citizenship by place of birth. As a result, more and more people are

\footnotetext{
${ }^{1}$ Common practice in the English-language literature on citizenship is to use the terms "dual citizenship" and "dual nationality" interchangeably, even though they sometimes have different connotations - with dual citizenship being more associated with the rights and obligations of citizens and dual nationality referring more to a formal status - and in some other languages they have more strictly differentiated meanings. Although in principle, I agree with this usage, in this article I generally use the term dual citizenship, rather than "dual nationality," for the sake of consistency and readability.
}

(C) 2005 by the Center for Migration Studies of New York. All rights reserved. 0197-9183/05/3903.0151 
holding two passports, voting in two countries, and developing loyalties and attachments to each "home" country than was ever the case before. ${ }^{2}$

Dual citizenship challenges one of the most stable and long-lasting assumptions of the modern era, namely that the nation-state constitutes the highest institution and the largest group of people - what Rupert Emerson (1960) calls a "terminal political community" - to which an individual can affirm allegiance. This notion of singular nationhood, which helped modern states to maintain their authority for centuries, has been weakening over the past few decades of economic and cultural globalization. The rise of dual citizenship is a particularly glaring element of this larger process of change, since it explicitly contradicts the concept and reality of singular membership in one national community.

Dual citizenship also raises important questions about who is included in, and who is excluded from, increasingly permeable national boundaries and how and why these issues are addressed and resolved differently across countries. As of yet, little reliable data exist on the number of dual citizens in the world today. In fact, most countries cannot even assess how many of their citizens are dual citizens, since such verification lies well beyond their means of control. According to some estimates, the number is as high as 5 million for Australians (Zappalà and Castles, 2000:56), well into the millions for citizens of the United States (Aleinikoff, 2000:139-140; Spiro, 2002:21), and also at least several million in Western Europe (Feldblum, 2000:478). The potential, and probably impending, liberalization of dual citizenship policies worldwide - along with a steady, if not increasing, rate of international marriages and children - will surely bring these figures up dramatically in the near future. In short, even though it was viewed in resoundingly negative terms as recently as 40 years ago, dual citizenship has already become an unavoidable and widespread phenomenon that both scholars and policymakers will soon have to confront.

Several scholars have begun to focus on dual citizenship in recent years, and their contributions have helped to trace the historical development of the concept and practice of dual citizenship and to highlight its growing importance in contemporary debates on migration and citizenship (Hansen

\footnotetext{
${ }^{2}$ Since some people are now citizens of three or even more countries, "multiple citizenship" might be a more accurate term than "dual citizenship." Nonetheless, in practice, almost all cases of multiple citizenship only involve two countries, and I therefore follow convention by discussing dual, not multiple, citizenship. But the analysis and findings that follow also apply to cases of "tri-citizenship" as well.
} 
and Weil, 2002; Spiro, 2002; Martin, 2002; Schuck, 2002; Koslowski, 2000b; Spiro, 1997; see also Aleinikoff and Klusmeyer, 2002). Yet much of the literature is devoted to normative questions about whether dual citizenship should be encouraged, and few scholars have thus far attempted to provide explicit and systematic empirical comparisons of dual citizenship policies - or even citizenship policies in general - across countries.

Although the increasing prevalence and importance of dual citizenship can hardly be questioned, one reason that might account for its relative neglect in most studies of citizenship involves the extraordinary difficulty in making sense of - much less categorizing clearly and analyzing its causes and/or effects - the national distinctions in policies on dual citizenship. While some countries have clear policies that either liberally allow or strictly prevent dual citizenship, most contain multiple contingencies and exceptions, and the policies are not always enforced as written. Complicating things further, as immigration and emigration flows have been increasing in this era of rapid globalization (e.g., Sassen, 1999), many countries have been changing or amending their citizenship laws - and how they are enforced over the past decade and even in the past few years.

The main objective of this article is to conceptualize, measure, and classify variation in dual citizenship policies in the countries of the European Union (EU). It focuses in particular on the fifteen "older" member-states of the EU - which I refer to as the "EU 15" - because they constitute a relatively coherent entity, consisting of countries that face similar pressures of immigration and globalization within the common framework of the EU and its institutional and juridical "harmonization." In comparative perspective, the EU spans a range of variation as wide as that of the entire industrialized world: some countries have been among the most liberal - comparable to Australia, for example - in allowing their citizens to hold two passports, and others have remained staunchly opposed - along the lines of Japan. In other words, the focus on the EU 15 provides for interesting contrast and variation within a relatively similar set of cases, thus allowing for a more systematic analysis than would be possible by looking at the entire world or the European continent.

The article proceeds in five main steps. First, I summarize the historical opposition to dual citizenship, focusing on the attempts by most states and international organizations to prevent it at all costs, culminating in the Council of Europe's "Convention on the Reduction of Cases of Multiple Nationality" in 1963. Then I turn to the more recent emergence of dual citizenship as an empirical reality, highlighting the factors that encouraged it 
over the past several decades. The next section introduces the three main components of citizenship policies that form the core of the empirical analysis, and the following section applies them to the EU 15 - in both the 1980s and the contemporary period, thus allowing for a consideration of change over time. In a very brief section, I also analyze the citizenship policies of the ten recent EU "accession countries" within the same empirical framework. And the final section links this empirical categorization to larger debates about convergence within the EU. While recognizing the importance of recent changes in several countries, I suggest that we are more likely to see lasting (albeit occasionally diminished) national differences, rather than convergence upon a common EU-wide citizenship policy.

\section{THE HISTORICAL OPPOSITION TO DUAL CITIZENSHIP}

While the emergence of dual citizenship is a relatively recent phenomenon, the opposition and downright hostility to it has a longer tradition. In 1849, historian George Bancroft, who later went on to become the first American ambassador to Germany, exclaimed rather provocatively that one should "as soon tolerate a man with two wives as a man with two countries; as soon bear with polygamy as that state of double allegiance which common sense so repudiates that it has not even coined a word to express it" (Bancroft, 1850:160, cited in Koslowski, 2000b:206). Bancroft not only expressed his views verbally, but he later institutionalized them in 26 different bilateral agreements known collectively as the "Bancroft Treaties," which effectively prevented dual citizenship for naturalized Americans who originally hailed from a series of different countries, many of them European.

In 1930, this opposition to dual citizenship became enshrined internationally by the League of Nations in its "Convention on Certain Questions Relating to the Conflict of Nationality Laws." This "Hague Convention" reflected the view that "it is in the interest of the international community to secure that all members should recognize that every person should have a nationality and should have one nationality only" (League of Nations, 1930). This position continued to hold sway in the post-WWII period, as the International Law Commission (of the United Nations) determined in 1954 that "all persons are entitled to possess one nationality, but one nationality only" (International Law Commission, 1954, cited in Koslowski, 2000b:207). In other words, the very concept of dual citizenship was seen as fundamentally opposed to the ongoing formation of the modern international order based on the nation-state. Even the author of the one academic 
study of dual citizenship reached the conclusion that it was "undesirable and should be abolished" (Bar-Yaacov, 1961:266).

From the Bancroft Treaties to the Hague Convention and beyond, the United States remained staunchly opposed to dual citizenship. President Ulysses S. Grant spoke out in 1874 against Americans "claiming the benefit of citizenship, while living in a foreign country, contributing in no manner to the performance of the duties of a citizen of the United States, and without intention at any time to return and undertake those duties, to use the claims to citizenship of the United States simply as a shield from the performance of the obligations of a citizen elsewhere" (Moore, 1906:713, cited in Spiro, 1997:1432-1433). A half century later, President Theodore Roosevelt referred to dual citizenship as "a self-evident absurdity" (Roosevelt, 1915:15, cited in Spiro, 1997:1430-1431). Moreover, even as recently as 1958, U.S. Supreme Court Justice Felix Frankfurter argued that "no man should be permitted deliberately to place himself in a position where his services may be claimed by more than one government and his allegiance be due to more than one" (Frankfurter, 1958:50, cited in Koslowski, 2000b: 204).

The concern in the United States reflected the fear that in the event of a European or world war, many naturalized citizens could be called to serve in the armies of their countries of origin, rather than in their "new" country. ${ }^{3}$ By ensuring that naturalization corresponded to a termination of other rights and obligations (especially military, of course, but also taxation) in the original country, the United States was able to continue its development as a country of immigrants, without risking the loss of their loyalty or support. Although the passing of time led to a much greater, and more permanent, integration of immigrants and their descendents into American society, the opposition to dual citizenship in the United States remained strong throughout much of the twentieth century as well.

In 1963, many European countries took a further step toward the consolidation of the singular citizenship principle when they signed the Council of Europe's "Convention on the Reduction of Cases of Multiple Nationality," the summary of which states that:

The Convention aims to reduce as far as possible the number of cases of multiple nationality, as between Parties. It lays down rules to reduce cases of multiple

${ }^{3}$ This fear dated back to the War of 1812 , during which relations between the British and the Americans deteriorated as a result of Britian's refusal to accept the naturalization of its former citizens as Americans (Spiro, 1997:22-23). 
nationality in the case of the acquisition of a new nationality or the renunciation of one nationality, and the legal consequences for persons concerned, including minor persons. It also contains provisions on military obligations in cases of multiple nationality (Council of Europe, 1963).

The Convention was signed and ratified by Austria, Denmark, France, Germany, Italy, Luxembourg, the Netherlands, Norway, and Sweden; Ireland, Spain, and the United Kingdom agreed only to the part of the Convention concerning "Military Obligations in Cases of Multiple Nationality."

Although it applied to just twelve European countries (and to three of them only partially), the Convention's policy on dual citizenship accurately represents the general consensus among states worldwide at the time, namely that people should not hold more than one citizenship. In the event of binational marriages and children, the prevailing argument was that spouses and children should choose the one country to which they would pay their allegiance in its entirety, rather than risk creating divided identities and loyalties, unclear tax implications, and possibly conflicting military duties.

Despite the Council of Europe's best efforts, however, the question of dual citizenship did not go away.

\section{THE GRADUAL EMERGENCE OF DUAL CITIZENSHIP IN EUROPE}

Until the mid-twentieth century, the traditional European model of the family consisted of spouses who were born and raised in the same country often in the same region, and even in the same town. Over the course of the century, however, and especially after World War II, the salience of these boundaries decreased significantly, as people became increasingly mobile and mixed and as Europe became more interconnected and integrated. More and more international marriages were producing binational children in the postwar period, and both parents and children often spent considerable time in, and felt loyalties and allegiance to, both countries, rather than just one.

At the same time, despite the best efforts of many states to prevent people from acquiring and assuming citizenship in two countries, more and more people began discreetly holding two passports, without either country knowing about the other, or even being able to find out. Although countries could regulate the naturalization of spouses in international marriages by demanding proof of renunciation of one spouse's prior citizenship, the real problem in terms of enforcement was with children, who could often follow the standard procedures to acquire the citizenship of both of their parents or 
of the country in which they were born (if that country granted citizenship by birth). Moreover, as the possibility of war grew more and more remote, and as the economy globalized such that political citizenship became seen as less important than economic participation, many countries began to liberalize the enforcement of their opposition to dual citizenship, which became increasingly tolerated and acknowledged, at least informally.

A wide array of additional factors help to explain the rise in dual citizenship over the past few decades, beyond the obvious fact that international travel, communication, and relationships have increased tremendously in the last half century. First, and most importantly, women's movements helped to do away with the old policy of "patrilineal ascription," by which children automatically acquired the citizenship of their father, and only if the father was not known would the child take on the mother's citizenship (Koslowski, 2000b; Hammar, 1985). This change allowed many more children to receive the citizenship of both parents, rather than just one, and it made dual citizenship a much more widespread de facto reality, even though often not allowed de jure.

A second important factor involves the (still ongoing) development of new norms and a regime of international human rights that apply to individuals regardless of their citizenship. Much of the historical opposition to dual citizenship had been predicated on fears of global instability and interstate conflict, which clearly no longer apply in the same way - at least within the advanced industrialized world. Although this has not served to create the "postnational" world that some analysts have predicted, international pressures based on individual human rights have undoubtedly created a much more tolerant and permissive attitude on the part of nation-states toward dual citizenship. As a result, for example, some countries (e.g., Germany and Switzerland) that historically have been "migrant-sending states" - and tolerated dual citizenship for their citizens who emigrated elsewhere but have recently become "net receiving states," have been under considerable domestic and international pressure to find a way to allow some of the immigrants in their country to hold dual citizenship as well (Koslowski, 2000b:212).

Other, more specific, factors involve changes made by some countries, which then have much wider ramifications for citizenship elsewhere around the world. For example, several "migrant-sending states" (including Colombia, the Dominican Republic, Ecuador, Italy, Mexico, and Turkey) have changed their policies, allowing citizens who emigrate to keep their citizenship even if they naturalize elsewhere - whereas before they had been forced 
to abandon their original citizenship if they acquired another - in the hope that they will form lobbies to influence their host country's policies toward the country of origin. The United Kingdom and Spain also have special arrangements with many of their former colonies to tolerate dual citizenship. On the side of "receiving" states, some countries (e.g., Canada and Australia) now explicitly allow dual citizenship, while others (e.g., the United States) no longer enforce the "renunciation clause" upon naturalization (Koslowski, 2000b:210-211).

As a result of these various factors, the Council of Europe has found itself under considerable pressure to amend or change its policy, lest it be completely outdated and ignored by its signatories. In 1993, the Council added a new protocol, written in rather vague language, that allows for dual citizenship "in order to encourage unity of nationality within the same family" (Council of Europe, 1993). By 1997, although still not officially abrogating the original 1963 Convention, the Council's Committee of Ministers passed the "European Convention on Nationality," which gives individual states the freedom to decide whether or not to allow dual citizenship and whether or not to require renunciation of a person's previous citizenship when acquiring another one. Not all of the signatories have ratified this new Convention as of yet, but its passage has helped to remove one of the major international impediments to dual citizenship in Europe. ${ }^{4}$

Although this institutional impediment has largely been removed, and the normative opposition that dated back at least a century has gradually weakened over the decades, dual citizenship has not become universally accepted or permitted. The following section introduces factors and categories that can help to understand the variation in policies within the countries of the EU.

\section{CHARACTERIZING AND CATEGORIZING CITIZENSHIP POLICIES}

Determining which EU countries allow dual citizenship, under what conditions, and with what frequency, is extremely difficult, not least because many countries have changed their laws in recent years. Moreover, one cannot simply create a "yes or no" binary classification of whether or not countries allow for dual citizenship, since dual citizenship is closely tied with

\footnotetext{
${ }^{4}$ Note that such a delay in ratification is not unusual, and many of the aforementioned treaties and amendments also took several years, and sometimes close to a decade, to be implemented.
} 
other elements of a country's national citizenship policy; to focus empirically on dual citizenship in isolation from those other main elements would be to miss the overall features - and possibly the change taking place over time within and across countries. This section therefore addresses dual citizenship within the context of citizenship policies in general.

Much of the empirical study of citizenship has either focused on a small number of countries (Brubaker, 1992; Joppke, 1999; Feldblum, 1999; Fetzer, 2000; Rubio-Marín, 2000), or it is concentrated in edited volumes (Nascimbene, 1996; Hansen and Weil, 2001, 2002; Aleinikoff and Klusmeyer, 2000, 2001; Hanagan and Tilly, 1999). While the case-study approach is certainly valuable, and it allows for a better understanding of the dynamics of citizenship policy within certain key countries, it is unable to trace systematically the variation across the countries of the EU. Similarly, although edited volumes generally group together some outstanding individual contributions, and collectively they cover the recent changes in a wide array of countries, they do not constitute rigorous comparative work on citizenship policy in the countries of the EU.

In recent years, several scholars have attempted to provide more explicit and systematic empirical comparisons of citizenship policies across countries (Castles and Davidson, 2000; Koslowski, 2000). Dilek Cinar (1994) and Patrick Weil (2001) have provided the most detailed empirical analyses of nationality laws in nine and twenty-five countries, respectively. What is still lacking in these studies, however, is a larger cross-national classification system to make sense of the vast amount of detail, which would allow for a more general categorization of countries. In other words, we still have very little clear understanding of how citizenship policies actually vary across the EU countries, going beyond the complex legal and technical specificities of each case, to a conceptual level that aggregates these differences into meaningful and tangible groupings and categories (see Hansen and Weil, 2001; see also Hansen 1998; Weil, 2001; for current national citizenship laws, see the Council of Europe website at <http://www.coe.int>.

In this section, I attempt to provide such a classification by breaking down each country's citizenship law into three key components: 1) whether or not it grants jus soli, or citizenship by birth, to the children of noncitizens; 2) the difficulty of its naturalization requirements, in particular the mandatory length of residency; and 3) whether or not it allows naturalized immigrants to hold dual citizenship. After briefly discussing the significance of each of these categories, I turn to the empirical evidence from the EU, focusing on two time periods: the contemporary period and the 1980s. I 
provide an overall index that measures the relative liberality or restrictiveness of a country's citizenship policies at both points in time, thus allowing for a consideration of the extent of convergence that has taken place since the 1980s.

\section{Citizenship by Birth}

One of the most important elements of a country's citizenship policies involves how newborn children acquire their citizenship. The standard classification that scholars have made involves the distinction between jus sanguinis ("law of blood") and jus soli ("law of the soil"), with the former indicating citizenship passed down by lineage and the latter referring to citizenship by birth in a given country. Although these two concepts have often been presented as a strict dichotomy - with countries having citizenship laws based on either one or the other - in reality all countries follow jus sanguinis (even the classic jus soli countries) (see Aleinikoff and Klusmeyer, 2002:7-8; Weil, 2001). The crucial test in terms of the relative liberality of a country's citizenship policy is whether children born on the soil of a foreign country (i.e., second-generation or third-generation immigrants) will automatically receive that country's citizenship. In practice, there is some variation in the way in which countries grant jus soli-some countries allow it regardless of the (legal or illegal) immigrant status of the parents, while others can be more restrictive and impose certain conditions - but the main distinction is between countries that allow for some form of jus soli and those that do not. The granting of citizenship by birth indicates a significantly more liberal citizenship policy.

\section{Naturalization Requirements}

Another crucial component of a country's policy on citizenship involves the relative transparency and ease with which foreign residents can become naturalized citizens. Naturalization requirements vary tremendously across countries (for an extremely detailed, but now already somewhat outdated, account of each country's requirements, see Nascimbene, 1996; for a more recent, but now already outdated in a number of cases, overview of the common requirements, see Weil, 2001), but they do include some common features, including a residency requirement - or the number of years a person must legally reside in a country before being eligible to apply for citizenship. Other requirements sometimes include knowledge of the "new" country's language and/or history, sufficient income, good character, the 
absence of a criminal record, and a loyalty oath (Weil, 2001:22-23). Unfortunately, it is impossible to know how these other requirements vary in practice, since they may genuinely constitute impediments in some cases, while not in others. ${ }^{5}$ Moreover, while it would be helpful to analyze national statistics on the number and type of applications, the percentage of acceptances or rejections, and the reasons why, such detailed statistics are lacking, and the accessible statistics on naturalization rates are often flawed, mainly because of unclear and unsystematic tabulation methods. ${ }^{6}$

Given these confounding legal technicalities and the lack of accurate statistics, the residency requirement appears to be not only the most important obstacle for immigrants to achieve naturalization, but also the best available - even if imperfect - measure by which to compare how naturalization requirements vary across countries.

\section{Acceptance of Dual Citizenship for Immigrants}

A closely-related component of citizenship policy - and of particular relevance for this article - involves whether countries allow their citizens to hold dual citizenship. A key distinction, however, is between countries that allow dual citizenship primarily for their émigrés who either naturalized or were born in another country and took on that citizenship as well and those

${ }^{5}$ Even shedding light on the intracacies themselves does not necessarily provide a clear picture of the acutal extent of naturalization. This is particularly the case for countries-such as Austria, Germany, Greece, Italy, Portugal and the United Kingdom-that follow "discretionary" naturalization, in which applications are arbitrarily approved or denied, without possibility for appeal. Complicating things further, the fact that a country uses discretionary naturalization does not automatically mean that such power is abused in an arbitrary and inconsistent manner; the "discretion" can just be a formality that does not significantly alter the outcome for applicants. But it does suggest the possibility that ultimate enforcement may not be as straightforward as the various terms of naturalization seem on paper, which is indeed the case in many countries.

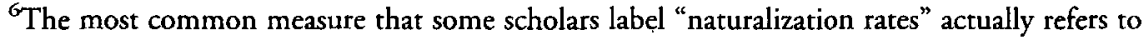
the number of acquisitions of citizenships each year as a percentage of the toral foreign population in that year, based on data from Eurostat. But those who use this data generally ignore the clear caveats and warnings about the inaccuracy of this data, which the authors of the report themselves discuss openly (see Salt et al., 2000:21, 164). Moreover, not only are the data themselves flawed, but the very concept of naturalization rates - even if they could be measured accurately - does not capture the social, political, and economic situation in the sending countries, which may itself cause tremendous variation in countries that have large immigrant populations from particular sending countries. (My thanks to an anonymous reviewer for convincing me to remove this factor from my analysis.) 
countries that allow first-generation immigrants to become naturalized citizens while still maintaining their current citizenship. In other words, there is an important difference between what might be called "emigrant dual citizenship," which comes at little direct "cost" to the emigrant or sending country and often serves to maintain and promote stronger cultural and linguistic connections to people who reside permanently in another country, and "immigrant dual citizenship," which allows for the integration of foreigners as naturalized citizens who plan to live, work, and settle permanently in the host or receiving country. This distinction is crucial, particularly for the historical countries of emigration - Germany, Greece, Ireland, Italy, the Netherlands, Portugal, Spain, and the United Kingdom - all of which have allowed and even encouraged their ethnic descendents or diaspora, who are citizens of other countries, to maintain their original citizenship, but only some of which have extended that option to immigrants within their borders. Immigrant dual citizenship is clearly the much higher standard, and it is associated with a more liberal citizenship policy.

By breaking down each country's citizenship laws and practices into these three key components - citizenship by birth, residency requirement for naturalization, and acceptance of dual citizenship for immigrants - and coding them systematically, both separately and in aggregate form, we can achieve a more nuanced and accurate picture of the variation within the EU countries than has been provided by individual case studies, edited volumes, and detailed policy analysis. That said, there are certainly limitations to such an approach, including the sacrificing of many of the qualifications and exceptions to each country's particular citizenship policies. In an ideal social science world, one would be able to develop a variety of more intricate categories in order to compare across countries. Unfortunately, however, the complexities of the laws themselves prevent this, and a rough approximation along the three major components of citizenship is the best available alternative.

\section{COMPARATIVE EVIDENCE FROM THE EU 15}

Having introduced the three key components of a country's citizenship policy, we can now turn to the empirical evidence from the countries of the EU. Table 1 presents the variation on each component for the EU 15 today, with any major changes since 1990 explained in the notes. The table shows extensive variation on all three components of citizenship policies, with seven of the countries granting jus soli, a wide range of residency require- 
TABLE 2

Citizenship Policy Index for the EU 15 in the Contemporary Period

\begin{tabular}{clc}
\hline Category & Country & Score \\
\hline Restrictive (0-1) & Austria & 0 \\
& Spain & 0 \\
Medium (2-4) & Denmark & 1 \\
& Greece & 2 \\
& Italy & 2 \\
& Luxembourg & 2 \\
& Finland & 3 \\
& Germany & 3 \\
& Portugal & 4 \\
& Sweden & 4 \\
& Belgium & 6 \\
& France & 6 \\
& Ireland & 6 \\
& Netherlands & 6 \\
& U.K. & 6 \\
\hline
\end{tabular}

Note: Author's classification based on the data in Table I. See the Appendix for a detailed breakdown of the various components and scoring of citizenship policies.

the United Kingdom - have rather liberal policies, and the seven remaining countries are in-between. Even within the "restrictive" and "medium" categories, there is some variation, showing that the EU 15 appear to be still very far from holding a common policy - or even similar policies - on citizenship.

While useful in terms of showing how the EU 15 compare to one another today, the results in Tables 1 and 2 are from one point in time, and they do not capture the extent to which any change may have been taking place. The question of change is particularly important in the context of debates about the extent to which increasing Europeanization is leading to a convergence of citizenship policies within the EU.

Table 3 presents the CPI scores for the EU 15 in the 1980s alongside the contemporary scores, showing the extent of change that has taken place in the interim. The table shows that for ten of the countries there has been no change on the whole. But the five countries that have changed their citizenship policies all moved in the positive direction on the scale, towards increasing liberalization. The nature of these particular changes merits some explanation.

The most common change resulted from a modification in the acceptance of dual citizenship for naturalized immigrants. Finland, the Nether-

soil will still receive Irish citizenship if at least one of their parents has resided in Ireland or the U.K. for three of the previous four years. In other words, while certainly more restrictive than it was previously, the new Irish law still grants jus soli, and in fact is still more liberal than other countries, such as Germany. 
TABLE 3

Changes in the Citnzenship Policy Index (CPI) for The EU 15 from the 1980S TO THE PRESENT

\begin{tabular}{lccc}
\hline \multicolumn{1}{c}{ Country } & CPI Score in the 1980s & CPI Score Today & Change \\
\hline Austria & 0 & 0 & no change \\
Germany & 0 & 3 & +3 \\
Luxembourg & 0 & 2 & +2 \\
Spain & 0 & 0 & no change \\
Denmark & 1 & 1 & no change \\
Finland & 1 & 3 & +2 \\
Greece & 2 & 2 & no change \\
Italy & 2 & 2 & no change \\
Sweden & 2 & 4 & +2 \\
Netherlands & 4 & 6 & +2 \\
Portugal & 4 & 4 & no change \\
Belgium & 6 & 6 & no change \\
France & 6 & 6 & no change \\
Ireland & 6 & 6 & no change \\
United Kingdom & 6 & 6 & no change \\
Note: Author's classification based on the data in Table 1. See the Appendix for a detailed breakdown of the various \\
components and scoring of cirizenship policies. Note that Italy did liberalize its policy on dual citizenship, which \\
is now accepted, but this was balanced by the engthening of its residency requirement from five to ten years, thus \\
resulting in no change in its overall CPI score.
\end{tabular}

lands, and Sweden have all begun to accept full dual citizenship - in all cases representing a significant departure from the previous policies, which had expressly opposed dual citizenship. ${ }^{8}$ Italy also began to accept dual citizenship, but the liberalization on this factor was balanced by lengthening of the residency requirement for non-EU citizens, from five to ten years, thus resulting in no change in its overall CPI score. Finally, Germany and Luxembourg both reduced their residency requirements rather significantly, resulting in a change in their CPI scores, in a more liberal direction.

Of all the countries that have changed their policies since the 1980s, Germany's new law, which came into effect in 2000 , resulted in the most wide-reaching change and the largest increase in its CPI score. Not only did Germany decrease the minimum residency requirement from fifteen to eight years, but the new law now allows for citizenship by birth. This change was particularly significant given the long and notorious history that a bloodbased definition of national membership has had in Germany. Today, unlike in the 1980s or at any time in German history, children of any nationality - provided that at least one parent has been a legal resident for at least

${ }^{8}$ Note that while the official policy of the Netherlands still does not allow for dual citizenship, numerous exceptions were established over the course of the 1990 s, resulting in a very liberal dual citizenship policy (see Vink, 2001). 
eight years - who are born on German soil now receive German citizenship automatically. Moreover, these children may actually hold dual citizenship until adulthood, but then they must choose one or the other before reaching the age of $23 .^{9}$ In short, the new law does now allow for jus soli, and in this sense it represents a remarkable change after decades of exclusive reliance on jus sanguinis, but that right may be revoked for people who are unwilling to give up their other citizenship. ${ }^{10}$

On the whole, this comparative analysis of the EU 15's contemporary citizenship policies and how they have changed over time shows that a number of countries have made important modifications to their citizenship policies since the 1980 s and that these have all been in the direction of liberalization. The most frequent change has reflected a greater tolerance of dual citizenship - not only for emigrants, but also for immigrants.

\section{COMPARATIVE EVIDENCE FROM THE $10 \mathrm{EU}$ "ACCESSION COUNTRIES"}

Since the EU added ten new members in May 2004, it is worth exploring briefly what might be the implications of the citizenship policies of the "accession countries" on the EU picture presented above. Tables 4 and 5 presents the Citizenship Policy Index for the ten new members today, based on the same criteria from Tables 1 and 2. Table 4 shows that there is considerably less variation in the ten accession countries. None of them grants citizenship by birth, the residency requirements are generally fairly lenient, and only three of the countries grant dual citizenship to naturalized immigrants.

\footnotetext{
${ }^{9}$ Since dual citizens must later give up one or the other citizenship, I have therefore coded Germany as "no" on the question of whether it allows for dual citizenship for immigrants. Moreover, adults who become naturalized citizens must still give up their prior citizenship. ${ }^{10}$ It should be added that the new law was a much watered-down compromise of the initial proposal of the newly elected Schroeder government in 1998, which had stressed full dual citizenship as its central objective. The proposal was defeated after a petition campaign against dual citizenship in the state of Hesse gathered more than one million signatures. Not only was the government embarassed by this campaign, but it lost badly in state elections, costing Schroeder his slim majority in the Bundesrat, and forcing him to compromise with opposition parties who still claim that "Germany is not a land of immigration." See Green (2000) and Martin (1998).
} 
TABLE 4

The Three Main Components of Citizenship Policies for the Ten EU “Accession COUNTRIes" in THE Contemporary PERIOD

\begin{tabular}{lccc}
\hline Country & $\begin{array}{c}\text { Citizenship by } \\
\text { Birth (Yes/No) }\end{array}$ & $\begin{array}{c}\text { Residency Requirement } \\
\text { for Naturalization } \\
\text { (Years) }\end{array}$ & $\begin{array}{c}\text { Acceptance of Dual } \\
\text { Citizenship for Immigrants } \\
\text { (Yes/No) }\end{array}$ \\
\hline Cyprus & No & 5 & Yes \\
Czech Republic & No & 5 & No \\
Estonia & No & 5 & Yes \\
Hungary & No & 8 & No \\
Latvia & No & 5 & No \\
Lithuania & No & 10 & Yes \\
Malta & No & 5 & No \\
Poland & No & 5 & No \\
Slovakia & No & 5 & No \\
Slovenia & No & 10 & \\
Sources: Author's analysis of the current national cirizenship laws, most of which are available through the Council of \\
Europe website, at http://www.coe.int/T/E/Legal_Affairs/Legal_co-operation/Foreigners_and_citizens/ \\
\multicolumn{2}{c}{ Nationality/Documents/Bulletin_and_national_legistlation/2Tables\%20MEMBER\%20STATES.asp. }
\end{tabular}

Putting this all together into the larger index, Table 5 shows that two of the countries are "restrictive," while the other eight are in the "medium" category - but most of those are on the low end of that grouping. Interestingly, the two highest scores among the ten accession countries are for the only two non-post-communist countries in the group (Cyprus and Malta). Overall, when compared to the index scores for the fifteen current EU members shown in Table 2, it appears that the new members are significantly more restrictive in terms of citizenship.

While suggestive, it is far too early to determine the implications of this finding. One might argue that since the applicant countries are already changing in so many other respects, perhaps they will be able to change their

TABLE 5

CtTIzenship Policy Index for the Ten EU "ACcession COUNTRIes"

\begin{tabular}{clc}
\hline \hline \multicolumn{2}{c}{ CIIZENSHIP POLICY INDEX FOR THE TEN EU "ACCESSION COUNTRIES" } \\
\hline Category & Country & Score \\
\hline Restrictive (0-1) & Lithuania & 0 \\
Medium (2-4) & Slovenia & 0 \\
& Czech Republic & 2 \\
& Estonia & 2 \\
& Latvia & 2 \\
& Poland & 2 \\
& Slovakia & 2 \\
& Hungary & 3 \\
& Cyprus & 4 \\
& Malta & 4
\end{tabular}

Note: Author's classification based on the data in Table 4. See the Appendix for a detailed breakdown of the various components and scoring of citizenship policies. 
citizenship policies quite radically and rapidly. But one could also claim that they will hold onto this one precious element of sovereignty even more dearly. In the context of this article, however, the introduction of the ten applicant countries into the mix reinforces the overall point that there is a great deal of variation in terms of the citizenship policies of the nowexpanded EU.

\section{CONCLUSION: IMMINENT CONVERGENCE OR LASTING DIFFERENCES?}

The main contribution of this article involves the measurement and classification of the cross-national variation in dual citizenship policies - and citizenship policies in general - within the fifteen, and now twenty-five, countries of the European Union. Within this final section, however, I consider the implications of these findings for larger debates about convergence within the $\mathrm{EU}$ and the future role of the nation-state and national distinctions.

The analysis of change shown in Table 3 shows clearly that a number of previously quite restrictive countries have liberalized their policies, particularly in the realm of dual citizenship. But does this noticeable change over the past few decades represent a relative narrowing of policies that will still remain nationally distinct, or does it portend a more absolute convergence upon a common EU citizenship policy, or at least very similar national policies?

Many scholars have indeed been proclaiming that a convergence process is undermining national distinctiveness, but they do so from two different - and otherwise opposed - perspectives. The first argues not only that policies among countries are converging, but that nation-states themselves are becoming increasingly irrelevant within the globalized economy and citizenry. As one proponent of this view argues, "Transnational migration is steadily eroding the traditional basis of nation-state membership, namely citizenship" (Jacobson, 1996:8). Another has claimed that "when it comes to social services (education, health insurance, welfare, unemployment benefits) citizenship status is of minor importance in the United States and in Western Europe" (Sassen, 1996:95). In short, this type of argument places great emphasis on the recent emergence of transnational and postnational norms based on individual human rights, which undermine the previously dominant system of nation-states (Soysal, 1994). 
A second type of argument about citizenship convergence does not view the nation-state as weakened by global forces. Rather, it is based on the contention that the extensive immigration of the postwar period throughout Western Europe has created a common need to better integrate immigrants in each society, resulting in a very similar pressure for reforming citizenship laws across countries. One study concludes, "Across Europe these reforms have broadly led to substantial, though not full, convergence in nationality law" (Hansen and Weil, 2001b:3; see also Aleinikoff and Klusmeyer, 2002: 7). Another claims that "starting from very different concepts of nationality, several OECD countries are progressively modifying their legislation to take into account the considerable presence of foreign communities within their borders. This process is leading to a gradual de facto convergence of their points of view with respect to nationality law" (OECD, 1995:172). In short, according to this view, although nation-states may be retaining their strength and coherence while adapting to new international norms, the policies they choose are becoming increasingly similar (see also Freeman, 1995; Joppke, 1998, 1999).

Although they are fundamentally opposed to one another in terms of their differing views on the strength/weakness of the nation-state, these two arguments share the belief that the previous classification of countries based on their historical national traditions has lost its relevance. In fact, they both repeatedly cite and critique the work of Rogers Brubaker (1992) on the different traditions of nationhood in France and Germany, pointing to the vast changes within Europe and the EU over the last decade.

Yet, while recognizing that a relative convergence has certainly been taking place - i.e., that the countries of the $\mathrm{EU}$ have been moving in a direction that brings them closer together, rather than farther apart - the findings of this article challenge the claim that they are converging upon a common standard or policy, either on citizenship in general or dual citizenship in particular. Indeed, the explicitly comparative perspective of this analysis suggests that important national differences remain, despite some movements toward relative convergence. A glance at the country groupings on Table 2 show a general pattern to anyone familiar with European history and geography: the countries with longer traditions of immigration and citizenship by birth have the most liberal citizenship policies and are the most tolerant of dual citizenship; the Nordic and Germanic countries are still generally less liberal and tolerant of dual citizenship (although the recent changes in Sweden, Finland, and Germany are notable); and the southern 
European countries are generally in-between (with the exception of Spain). ${ }^{11}$ Although this does not rule out a possible "contraction" of this continuum over time, it does suggest that an actual convergence is not quite as imminent as some scholars have claimed and that national (and sub-regional) differences may be longer lasting than has been recognized.

Moreover, the issue of citizenship, and in particular dual citizenship which can imply a "special" status for people who have not one, but two passports and who can vote in not one, but two countries - can be, and has been, easily politicized in a way that triggers a fierce nationalist (and possibly anti-EU) reaction in the general population. ${ }^{12}$ Although many EU countries have been revising and reinterpreting their citizenship laws in recent years, one should not underestimate the extent to which anti-immigrant xenophobia - which has increased significantly across Europe over the last decade, by any measure - may influence political elites, who tend to be more responsive to the short-term demands of the electorate than to long-term demographic needs or idealistic goals. The relevant point here is simply that these countervailing pressures, negotiations, and contestations may well produce unpredictable and different effects across countries, rather than converge upon a single EU standard.

In other words, in terms of contemporary dual citizenship policies, not only is it probably too early to declare the end of the nation-state, but it may be too early to declare the end of historically-rooted national distinctions as well. ${ }^{13}$ In fact, however much it has been critiqued in recent years, Brubaker's argument may still be more persuasive than the others, and it is therefore worth concluding with it here. Brubaker asked the following question: "Why have citizenship policies so far escaped the convergence to which immigration policies have been subjected? What is special about citizenship?" (Brubaker, 1992:180). His answer: "Citizenship in a nation-state is inevita-

${ }^{11}$ One could argue, however, that Spain is more tolerant of dual citizenship than my coding has granted, given that it actively supports dual citizenship for people of Spanish heritage.

${ }^{12}$ This is precisely what led to the defeat of the ambitious reform in Germany-which included full jus soli and dual citizenship, but ended in a much diluted compromise-that was initially proposed by Chancellor Schroeder upon taking office in 1998.

${ }^{13}$ In this sense, I follow the "empirically grounded middle position" proposed by Christian Joppke (1999:4), who argues that "We can observe both, a stubborn insistence of states to maintain control over their borders and increasing human-rights constraints on traditional sovereignty; a proliferation of membership categories and pressures to remold them as a unitary citizenship; a persistence of distinct national models of handling (and containing) ethnic diversity and multicultural pressures on the monocultural texture of nations." 
bly bound up with nationhood and national identity, membership of the state with membership of the nation. Proposals to redefine the legal criteria of citizenship raise large and ideologically charged questions of nationhood and national belonging.... The politics of citizenship today is first and foremost a politics of nationhood" (Brubaker, 1992:182).

While it is obviously too early to determine in any conclusive way, the evidence shown in this article suggests that the "politics of nationhood" still remain surprisingly central within the various discussions and reforms of citizenship policies - certainly in terms of dual citizenship. Within the countries of the EU, it appears that dual citizenship policies have still not converged to nearly the same degree as in other economic and social areas, and that national distinctiveness will remain a lasting feature of citizenship.

\section{APPENDIX}

\section{Coding of the Variables}

The Citizenship Policy Index (CPI) is based on a simple additive formula, with 2 points for each of the three criteria, allocated in the following way: Citizenship by birth is coded as either 0 (not allowed) or 2 (allowed).

Residency requirement for naturalization is coded as follows: countries that require at least ten years are coded 0 (difficult); those that require six to nine years of residence are coded 1 (medium); and those that require five years or less are coded 2 (easy).

Acceptance of dual citizenship for immigrants is coded as either 0 (naturalized citizens must relinquish their prior citizenship) or 2 (naturalized immigrants can retain their previous citizenship).

\section{REFERENCES}

Aleinikoff, T. A.

2000 "Between Principles and Politics: U.S. Citizenship Policy." In From Migrants to Citizens: Membership in a Changing World. Ed. T. A. Aleinikoff and D. Klusmeyer. Washington, DC: Carnegie Endowment for International Peace. Pp. 119-172.

Aleinikoff, T. A. and D. Klusmeyer, eds.

2002 Citizenship Policies for an Age of Migration. Washington, DC: Carnegie Endowment for International Peace.

2001 Citizenship Today: Global Perspectives and Practices, International Migration Publications. Washington, DC: Carnegie Endowment for International Peace. 
2000 From Migrants to Citizens: Membership in a Changing World. Washington, DC: Carnegie Endowment for International Peace.

Bancroft, G.

1850 "Letter to Lord Palmerson, Jan. 26, 1849," reprinted in Sen. Ex. Docs. 38, 36th Congress, 1st Session.

Bar-Yaacov, N.

1961 Dual Nationality. New York: Praeger.

Brubaker, R.

1992 Citizenship and Nationhood in France and Germany. Cambridge, MA: Harvard University Press.

Cinar, D.

1994 "From Aliens to Citizens: A Comparative Analysis of Rules of Transition." In From Aliens to Citizens: Redefining the Status of Immigrants in Europe. Ed. R. Bauböck. Aldershot, UK: Avebury. Pp. 49-72.

Council of Europe

1993 "Second Protocol amending the Convention on the Reduction of Cases of Multiple Nationality and Military Obligations in Cases of Multiple Nationality," available at <http://conventions.coe.int/>.

1963 "Convention on the Reduction of Cases of Multiple Nationality" summary, available at $<$ http://conventions.coe.int/>.

Emerson, R.

1960 From Empire to Nation: The Rise of Self-Assertion of Asian and African Peoples. Cambridge, MA: Harvard University Press.

Ersbøll, E.

2001 "Nationality Law in Denmark, Finland and Sweden." In Towards a European Nationality: Citizenship, Immigration, and Nationality Law in the EU. Ed. R. Hansen and P. Weil. New York: Palgrave. Pp. 230-254.

Feldblum, M.

2000 "Managing Membership: New Trends in Citizenship and Nationality Policy." In From Migrants to Citizens: Membership in a Changing World. Ed. T. A. Aleinikoff and D. Klusmeyer. Washington, DC: Carnegie Endowment for International Peace. Pp. 475499.

1999 Reconstructing Citizenship: The Politics of Nationality Reform and Immigration in Contemporary France. Albany, NY: SUNY Press.

Fetzer, J. S.

2000 Public Attitudes toward Immigration in the United States, France, and Germany. Cambridge: Cambridge University Press.

Frankfurter, F.

1958 "Majority Opinion," In Perez v. Brownell, 356 U.S.

Green, S.

2000 "Beyond Ethnoculturalism? German Citizenship in the New Millenium," Germany Politics, 9(3):105-124. 
Hammar, T.

1985 "Dual Citizenship and Political Integration," International Migration Review, 19(3): 438-450.

Hanagan, M. and C. Tilly, eds.

1999 Extending Citizenship, Reconfiguring States. Lanham, MD: Rowman \& Littlefield Publishers.

Hansen, R.

1998 "A European Citizenship of a Europe of Citizens? Third Country Nationals in the EU," Journal of Ethnic and Migration Studies, 24(4):751-768.

Hansen, R. and P. Weil, eds.

2002 Dual Nationality, Social Rights, and Federal Citizenship in the U.S. and Europe: The Reinvention of Citizenship. New York: Berghahn Books. eds.

2001a Towards a European Nationality: Citizenship, Immigration and Nationality Law in the EU. New York: Palgrave.

2001b "Introduction: Citizenship, Immigration and Nationality: Towards a Convergence in Europe?" In Towards a European Nationality: Citizenship, Immigration, and Nationality Law in the EU. Ed. R. Hansen and P. Weil. New York: Palgrave. Pp. 1-33.

International Law Commission

1954 International Law Commission Yearbook 1954 II, sec. 42, 48.

Jacobson, D.

1996 Rights across Borders: Immigration and the Decline of Citizenship. Baltimore: Johns Hopkins University Press.

Joppke, C.

1999 Immigration and the Nation-State: The United States, Germany and Great Britain. Oxford: Oxford University Press.

1998 "Why Liberal States Accept Unwanted Immigration," World Politics, 50(2):266-293.

Koslowski, R.

2000a Migrants and Citizens: Demographic Change in the European State System. Ithaca: Cornell University Press.

2000b "Demographic Boundary Maintenance in World Politics: Of International Norms on Dual Nationality." In Identities, Borders, Orders: Rethinking International Relations Theory. Ed. M. Albert, D. Jacobsen and Y. Lapid. Minneapolis: University of Minnesota Press. Pp. 203-223.

League of Nations

1930 "Convention on Certain Questions Relating to the Conflict of Nationality Laws," available at <http:www.austlii.edu.au/au/other/dfat/treaties/1938/4.html>.

Martin, D. A.

2002 "New Rules for Dual Nationality." In Dual Nationality, Social Rights, and Federal Citizenship in the US and Europe: The Reinvention of Citizenship. Ed. R. Hansen and P. Weil. New York: Berghahn Books. Pp. 34-60.

Martin, P.

1998 "Germany: Reluctant Land of Immigration." Washington, DC, American Institute for 
Contemporary German Studies. Available at: <http://www.aicgs.org/publications/ PDF/martin.pdfs (accessed January 29, 2004).

Moore, J. B.

1906 A Digest of International Law, 553.

Nascimbene, B., ed.

1996 Nationality Laws in the European Union. Milan: Giuffrè Editore.

OECD

1995 SOPEMI: Trends in International Migration, Annual Report 1994. Paris: OECD.

Roosevelt, $\mathrm{T}$.

1915 "When Is an American Not an American?" Metropolitan Magazine, June.

Rubio-Marín, R.

2000 Immigration as a Democratic Challenge: Citizenship and Inclusion in Germany and the United States. Cambridge: Cambridge University Press.

Salt, J., J. Clarke and S. Schmidt

2000 "Patterns and Trends in International Migration in Western Europe." Luxembourg: Office for Official Publications of the European Communities.

Sassen, $S$.

1999 Guests and Aliens. New York: The New Press.

1996 Losing Control? Sovereignty in an Age of Globalization. New York: Columbia University Press.

Schuck, P. H.

2002 "Plural Citizenships." In Dual Nationality, Sacial Rights, and Federal Citizenship in the U.S. and Europe: The Reinvention of Citizenship. Ed. R. Hansen and P. Weil. New York: Berghahn Books. Pp. 61-99.

Soysal, Y. N.

1994 Limits of Citizenship: Migrants and Postnational Membership in Europe. Chicago: University of Chicago Press.

Spiro, $\mathrm{P}$.

2002 "Embracing Dual Nationality." In Dual Nationality, Social Rights, and Federal Citizenship in the U.S. and Europe: The Reinvention of Citizenship. Ed. R. Hansen and P. Weil. New York: Berghahn Books. Pp. 19-33.

1997 "Dual Nationality and The Meaning of Citizenship," Emory Law Journal, 46(4):14111485.

Vink, M. P.

2001 "The Limited Europeanization of Domestic Citizenship Policy: Evidence from the Netherlands," Journal of Common Market Studies, 39(5):875-896.

Weil, $P$.

2001 "Access to Citizenship: A Comparison of Twenty-Five Nationality Laws." In Citizenship Today: Global Perspectives and Practices. Ed. T. A. Aleinikoff and D. Klusmeyer. Washington, DC: Carnegie Endowment for International Peace. Pp. 17-35.

Zappalà, G. and S. Castles

2000 "Citizenship and Immigration in Australia." In From Migrants to Citizens: Membership in a Changing World. Ed. T. A. Aleinikoff and D. Klusmeyer. Washington, DC: Carnegie Endowment for International Peace. Pp. 32-81. 